\title{
The Lack of Political Activism Among Today's Black Student-Athlete
}

\author{
Reese Renford, Ph.D. \\ California State Polytechnic University, Pomona
}

Abstract: The brief time between 1968 and 1972 was the only period in American sport history that black athletes were outwardly committed to the struggle for liberation and equality. Throughout American history, the black athlete has been socialized to be politically unconscious, inactive, and docile. During the era in which Dr. Harry Edwards led the revolt of the black athletes, the activism of the athletes matched the injustices that existed in American society. With the rise of the prison industrial complex, racial profiling, the extraordinary racial disparities in the criminal justice system, the disdain of our former black president, ubiquitous black poverty, and the incessant incidents of police brutality, this article examines how the activism of today's black student-athletes does not match the glaring injustices that exist in American society. The protest by the University of Missouri's football team in 2015, which resulted in the president of the university resigning, highlighted the power of black student-athletes when their voice is collective, animated, and purposeful. NCAA Division I athletics has become a $\$ 10$ billion industry and black-student athletes are responsible for generating a significant amount of this revenue. Today, they have the leverage, influence, and power to change many policies that affect their own development and the condition of those in their communities. This paper examines the lack of activism and political consciousness among today's black-student athletes and calls for strategies to be implemented to increases the consciousness and the empowerment of this group.

Keywords: black student-athletes, consciousness, activism, liberation, the Colin Kaepernick effect

The system of collegiate sports has effectively socialized the black student-athlete to be politically unconscious and docile. Carter G. Woodson's words in 1933 in The Mis-Education of the Negro have been accurate for most of the century:

When you control a man's thinking you do not have to worry about his actions. You do not have to tell him not to stand here or go yonder. He will find his "proper place" and will stay in it. You do not need to send him to the back door. He will go without being told. In fact, if there is no back door, he will cut one for his special benefit. His education makes it necessary. (Woodson, 1990, back cover)

With all of the mayhem facing young black men in our society, there have been virtually no collective protests by black student-athletes regarding the incessant injustices that exist in American society. The black student-athletes on college campuses collectively have more potential leverage, influence, and power than any young black sub-group in America. However, their currency in changing policies that affect their own development and policies that affect their communities has been woefully underutilized. 
The Black Lives Matter movement began in 2013 with the acquittal of white assailant, George Zimmerman, in the shooting death of black teenager, Trayvon Martin. The movement's presence became more prominent with the death of another unarmed black man, Michael Brown, which led to the protests and unrest in Ferguson, Missouri. Opal Tometi, one of the founders of the movement stated:

We started using social media to connect this community and to amplify the message that our lives matter, despite a society and a system that continues to devalue and continues to dispose of us in a way that is egregious. It's deplorable, and we know it's happening. (Valley, 2016)

As dynamic and animated as the Black Lives Matter movement has been, it has not had substantive impact on the activism of black-student athletes.

For black student-athletes who are fearful of losing their scholarships, it is understandable that they are passive. However, protests and symbolic statements of solidarity do not have to be violent or disruptive. Someone should expose them to non-disruptive protest strategies. Wearing a simple black armband, a black wristband, black socks, or any item that symbolizes solidarity and protests can be initiated without disruption to the university or to the team's standard operating procedures.

The United States Supreme Court ruled in the 1969 case of Tinker v. Des Moines that students at school retain their First Amendment right to free speech (Iannacci, 2017). In this case, Tinker wore a black armband to school to protest the Vietnam War (Iannaci, 2017). Writing for a 7-2 majority, Justice Abe Fortes famously wrote that students and teachers do not "shed their constitutional rights to freedom of speech or expression at the schoolhouse gate." Fortes went on to write that a student's speech cannot be censored unless it "materially disrupts classwork or involves substantial disorder or invasion of the rights of others (Iannacci, 2017).

The Tinker case has given black student-athletes the constitutional right to protest - a right that they have not collectively and systematically used since the late 1960s. In the midst of so much turmoil facing the black community today, the lack of activism among this group is problematic.

Until the late 1960s, many black athletes had been effectively socialized to be nonpolitical. The years between 1968 and 1972 were about the only period in American sport history that blacks were outwardly committed to the struggle for black liberation and equality. In 1968, protests by black athletes were widespread. The activism of these black athletes reflected the socio-political environment of the era. According to Dr. Harry Edwards (1969), the black athlete revolt was a culmination of the extreme hatred and injustice in America, manifested in the murder of Malcolm X, the bombing of the church that killed four black girls in Birmingham Alabama, the murder of Medgar Evers, the assassination of Dr. Martin Luther King Jr., and others.

Although the proposed Olympic boycott of the 1968 Mexico games failed, black athletes challenged the system like they had never done before and have never done since. Tommie 
Smith and John Carlos symbolized the new militancy among athletes when they raised a balled fist-symbolic of black liberation and black power - as they accepted their gold and silver medals respectively and listened to the American national anthem (Edwards, 1969).

The militancy and protest spirit of Smith and Carlos emboldened black student-athletes on college campuses to become active. Black student-athletes during this era reacted to the unfair practice of racial stacking on the field and monitoring of who they dated off the field through protests and speaking out. These athletes risked their scholarships by boycotting team practices, banquets, and competitions (Harris, 1993).

In 1968, black athletes threatened to protest all athletic events at the University of Washington. The football players accused the head coach, Jim Owens, of blatant discrimination. In the same year, Wayne Vandenburg, the coach of the University of Texas, El Paso, dismissed nine track and field athletes from his team for protesting the Mormon Church's treatment of blacks. Moreover, in 1969, Coach Lloyd Eaton dismissed fourteen football players from his team because they wanted to protest and draw attention to the Mormon Church's policies regarding blacks. Fourteen black football players were thrown off the team at Indiana University for missing practice two consecutive days in protest (Wiggins, 1997). Black athletes were involved in rebellions at Syracuse University, Oregon State University, Michigan State University, San Francisco State University, and the University of California at Berkeley, among other schools (Wiggins, 1993). At no other time in American sport history have black athletes publicly identified with the struggle and outwardly challenged the system (Wiggins, 1997).

When Maurice Clarett was a freshman running back for the Ohio State Buckeyes in 2002, he was denied the opportunity to go to the funeral of a close friend during preparations for the national championship bowl game against the University of Miami. The Ohio State administration stated that Clarett could not leave to go to his friend's funeral because he did not sign all of the proper paperwork. Clarett insisted that was not the case. He went on to state that the university only cared about making money; they did not care about human life. Clarett went beyond discussing the funeral and began discussing the glaring hypocrisy of college football. The Ohio State University made $\$ 13$ million from the national championship game at the Fiesta Bowl, which they won. However, as Clarett responded, it is not fair to have all of that money spent on a game when there is so much poverty right around the campus of Ohio State in Columbus.

Clarett's statements were stinging and poignant. This was the first time in two decades that a high-profile black student-athlete had harshly and publicly criticized the hypocrisy of the athletics machine in the United States. Ohio State was reluctant to chastise Clarett because they needed him to win the national championship. As an indispensable athlete on the Buckeyes squad, Clarett used his currency to condemn the contradictions of college athletics. As athletes, black men are worshiped and lionized. Stripped of their jerseys, pads, and eligibility, the same black men on the streets are treated with blatant disdain - treated as menaces to society (Renford, 2004).

Clarett and the courageous athletes who participated in the black athlete revolts of the late 1960s and early 1970s stand as unique examples of black student-athletes who dared to stand up 
to the all-powerful system. Over the past decade, there have been few examples of black studentathlete activism on college campuses. This is troubling.

In 2015, two major events challenged the status quo of college athletics in monumental ways. First, the Northwestern football team's drive to have a union and former black-student athlete and UCLA basketball star, Ed O'Bannon, boldly challenged the system. And, although the National Labor Relations Board did not embrace the idea of college athletes unionizing because "it would disrupt the competitive balance in college football," the point was emphatically made (Dahlberg, 2015, para.2). The NCAA agreed to improve the conditions of college athletes in a few ways. O'Bannon and 19 others filed a lawsuit that charged the NCAA with violating antitrust laws. The O'Bannon lawsuit coupled with the Northwestern movement created public awareness and change (Daily Herald, 2015). These are unique examples of activism. The Northwestern case is not exclusively about black student-athletes and Ed O'Bannon is not a current black student-athlete.

Although black athletes have made up the majority of the players on the football and basketball teams of the 76 colleges in the six big athletic conferences, their voices of protest are muted. This would be understandable if there was nothing to protest, but black student athletes have had to endure the seemingly countless deaths of black men at the hands of police over the past few years: Eric Garner, Mike Brown, Tamir Rice, Laquan McDonald, Walter Scott, Freddie Gray, Alton Sterling, Philando Castile, Terence Crutcher. And again, Trayvon Martin, who was murdered by security guard George Zimmerman, whose death precipitated the Black Lives Matter movement.

I asked a friend who is an athletic administrator at the University of Tulsa whether there was much outcry from his student-athletes when police officer Betty Jo Shelby was acquitted of first-degree manslaughter charges in 2017 for shooting Terence Crutcher, an unarmed black man who had his hands up. The family of Crutcher expressed outrage over the jury's verdict. This tragedy was captured on video and seemed to be a clear-cut case of homicide (Stanglin, 2018). According to my friend, there was no uproar among his black student-athletes in reaction to this case.

In Texas, a white police officer killed unarmed Jordan Edwards in 2017. Edwards was a straight "A" student and a member of Mesquite High School's football team (Schrader, 2017). There was no collective protest or show of solidarity for Jordan Edwards' family from the blackstudent athletes at the most prominent schools for athletics in the state: University of Texas, Texas A\&M, Southern Methodist University, Texas Christian University, Baylor, and Texas Tech, Houston. Despite the fact that black student-athletes help these schools generate hundreds of millions of dollars in revenue, they have no voice in their own human development at these institutions and are muted in their collective protest of the injustices in their communities.

Black student-athletes of the 1960s and 70s captured the zeitgeist of advocacy. Their activism matched the injustices that were taking place in American society. With the rise of the prison industrial complex, racial profiling, the extraordinary racial disparities in the criminal justice system, the disdain of our former black president, the disdain of blacks by our current president, ubiquitous black poverty, and the incessant incidents of police brutality, the in- 
activism of today's black student athletes does not match the glaring injustices that exist in American society.

The University of Missouri football team's stance against the university's discriminatory practice in 2015 is a contemporary example of the power of the black student-athlete's voice when it is collective, animated, and purposeful. Graduate student, Jonathan Butler, went on a hunger strike to protest racism at the university. The football players joined Butler's movement by threatening not to play in one of their upcoming games as a form of protest. This was a potential public relations nightmare for the University of Missouri because not only did they face the financial loss from its football team skipping a game, they also faced the embarrassing publicity of being a university that was hostile toward minority students. There are 200 college football teams that mostly have black athletes on their rosters; the Missouri case is the exception.

According to Dr. Shaun Harper, Director of the Center for the Study of Race and Equity in Education at the University of Pennsylvania, "If you look at black undergraduate men, they could do very little in defense of themselves, given their small numbers." Harper went on to write, "Given the large number of black men on the football team there, they can do something and they did something" (Cameron \& DePillis, 2015, para.3). Harper captures the significance of the Mizzou protest when he states, "I do not think they knew until this most recent situation just how much collective impact and influence they could have... without the black players, you have no football team" (Cameron \& DePillis, 2015,para.6).

In 2015, the University of Minnesota's football players went on strike. They refused to play a game until their president resigned for mishandling a series of racist incidents on campus. The president resigned as a result of this pressure. In 2016, the team boycotted to protest the suspension of 10 of their teammates over sexual assault allegations. Although they eventually called off their boycott, the point was made. The university administrators listened to them and made their adjustments. Their head coach, Tracy Claeys, tweeted during this episode: "Have never been more proud of our kids. I respect their rights \& support their effort to make a better world!" (Gibbs, 2016). These cases are exceptions but show what is possible through collective action.

According to Cork Gaines (2016), in fiscal year 2015, the 231 NCAA Division I schools with data available generated a total of $\$ 9.15$ billion in revenue. There were 24 schools that made more than $\$ 100$ million in athletics. Moreover, the black student-athletes are prominent in the revenue-generating sports on these campuses. What is the responsibility of these money-making machines to ensure the human development of their black-student athletes that are responsible for much of the revenue that is generated? There should be just as much attention put on each program's graduation rates as there is put on making it into football bowl games or into the NCAA tournament for basketball. There should also be emphasis on creating internships and job opportunities for the overwhelming majority of these athletes that do not make it to the professional ranks.

The Southeastern Conference (SEC) is made up of teams from Georgia, Alabama, Mississippi, Florida, Tennessee, Louisiana, South Carolina, Kentucky, Arkansas, Texas, and Missouri. The stadium capacity for SEC football teams ranges from 40,350 to 102,500. Nearly 
all 14 SEC football stadiums are filled to capacity during games. Furthermore, the composition of the fans in these stadiums is about 98 percent white. The only blacks in the stadium are usually the family members and friends of the players and the players themselves.

Over 70 percent of starters on any given SEC football or basketball team are black. The fans know their favorite player's height, weight, and 40-yard dash time. They know their stats and their hometown. They wear their jerseys at games. They seek their autographs and seek photos with them. The white, mostly conservative, male students on college campuses are enamored with the black student-athlete. But, it is a strange attachment.

The same young men from the Sigma Alpha Epsilon fraternity at the University of Oklahoma who worshiped the University of Oklahoma's football team were caught on tape on a bus ride chatting with untamed fervor:

There will never be a n-gger in SAE There will never be a n-gger in $S A E$

You can hang him from a tree but he can never sign with me. There will never be a n-gger in SAE (Kingkade, 2015)

This love-hate affair with young black men is also reflected in our politics. In 2008 and in 2012, Obama lost every SEC state except for Florida. It is paradoxical to see a demographic that is so obsessed with the black athlete also be so hateful toward the black president. What does this paradox tell us? It tells us that many whites can tolerate blacks only when they are entertaining but cannot tolerate a conscious black with an opinion or a perspective about politics and the world.

Colin Kaepernick's decision to take a knee before the game during the national anthem in protest of racism, discrimination, police brutality, and economic inequality in America sparked outrage, solidarity, and widespread debate. Kaepernick inspired other black athletes from little leaguers through the college and professional ranks to take a stand against the injustices facing black America. He coupled his symbolic activism with $\$ 400,000$ in donations to a variety of grassroots organizations that fight for social justice (Armour, 2017).

Kaepernick's protest should be examined as a case study on courage and political consciousness. It also, however, should be examined within the context of what happens to a black athlete who speaks out about the system. Embedded in the First Amendment of the U.S. Constitution is the "right to petition the government for redress of grievances." Kaepernick exercised this right in a nonviolent fashion and the same people who cheered him on as a talented dual-threat quarterback quickly turned him into a pariah. They viewed his actions as treasonous and ungrateful and viewed him as a traitor.

The Kaepernick case gives us a clear example of the behavior that white America will not tolerate from its black athletes. Their mantra is to play, entertain, and be grateful. Their position is for the black athlete not to be concerned with the myriad of issues that affect themselves, their families, and their communities. 
I am always surprised at how football coaches allow players to wear earrings and necklaces on the playing field. In many ways, this is the player rebelling against conformity. And, if this is allowed, surely a black armband, a black wristband, black socks, or any item that symbolizes solidarity and protests should be tolerated.

On college campuses, the socialization of black student-athletes to be non-political, apathetic, passive, and unconscious has been remarkably effective. This is a tragic phenomenon given the constant crises and peril in which the black community finds itself. Because black student-athletes have the leverage, influence, and power to change many policies that affect their own development and the condition of those in their communities, it is incumbent upon them to find nonviolent, symbolic, substantive, and meaningful ways to use their collective voice like their predecessors of the late 1960s and early 1970s to fight for change. When Muhammad Ali protested the draft to fight in the Vietnam War, America turned its venom toward him. Ali, standing on principal, famously said that no Viet Kong had ever called him the N-word. In the end, Ali became one of America's most popular icons. People came to respect him for being a man of great moral character and integrity.

The 2017 protests by white nationalists in Charlottesville, Virginia, which killed one counter-protester and injured 19, is a prime scenario for black students-athletes to unite and to denounce bigotry. Their voices of solidarity could come in a myriad of forms. With incidents such as this, this population does not have to remain powerless on the fringes. The advent of social media has made it easier to communicate and to organize. With this said, there needs to be leaders among this population that have the consciousness and savvy to organize. Perhaps this paper can be the stimulus for collective action strategies among this population. 


\section{References}

Armour, N. (2017, March 2). Why Colin Kaepernick's protests will resonate. USA Today. Retrieved from https://www.usatoday.com/story/sports/columnist/nancyarmour/2017/03/02/colin-kapernick-national-anthem-protest-san-francisco49ers/98642198/

Cameron, D., \& DePillis, L. (2015, November 10). How racial tensions at the University of Missouri have exposed the power of black athlete. The Washington Post. Retrieved from https://www.washingtonpost.com/news/wonk/wp/2015/11/10/how-racial-tensions-at-theuniversity-of-missouri-have-exposed-the-power-of-blackathletes/?utm_term $=.8 \mathrm{~d} 3 \mathrm{~d} 2851339 \mathrm{a}$

Dahlberg,Tim. (2015, August 17). Athletes Are Winners Even On A Day They Lost. Associated Press. Retrieved fromhttp://collegefootball.ap.org/article/column-athletes-are-winnerseven-day-they-lost

Edwards, H. (1969). The Revolt of the Black Athlete. New York, NY: The Free Press.

Gaines, C. (2016, October 14). The difference in how much money schools make off of college sports is jarring, and it is the biggest obstacle to paying athletes. Business Insider. Retrieved from http://www.businessinsider.com/ncaa-schools-college-sports-revenue2016-10

Gibbs, L. (2016, December 16). Minnesota football players boycott bowl game to protest suspensions for alleged gang rape. ThinkProgress. Retrieved from https://thinkprogress.org/minnesota-football-players-boycott-bowl-game-to-protestsuspensions-for-alleged-gang-rape-79d973e9f09d/

Harris, O. (1993). African-American predominance in collegiate sport. In Dana Brooks and Ronald Althouse (Eds.), Racism In College Athletics: The African-American Athlete's Experience (pp. 51-74). Morgantown, WV: Fitness Informational Technology, Inc.

Iannacci, N. (2017, February 24). Tinker v. Des Moines: Protecting student free speech. Constitution Daily, National Constitution Center. Retrieved from https://constitutioncenter.org/blog/tinker-v-des-moines-protecting-student-free-speech

Kingkade, T. (2015, March 8). Oklahoma Frat Boys Caught Singing, 'There will Never be a $\mathrm{N}^{* * * * *}$ in SAE'. Huffington Post. Retrieved from http://www.huffingtonpost.com/2015/03/08/frat-racist-sae-oklahoma_n_6828212.html

Renford, R. (2004). American Paradox: Young black men. Durham, NC: Carolina Academic Press.

Schrader, A. (2017, May 7). Where is End? Another sad funeral for black teen gunned down by white cop. New York Daily News. Retrieved from 
http://www.nydailynews.com/news/national/prior-black-slay-vics-cops-recalled-jordanedwards-funeral-article-1.3142813

Stanglin, Doug (2017, May 18). Tulsa officials appeal for calm after white officer's acquittal. USA Today. Retrieved from https://www.usatoday.com/story/news/nation/2017/05/18/tulsa-officials-appeal-calmafter-white-officers-acquittal/101823058/

Tarm, M. (2015, August 17). Ruling to allow college athletes to unionize is thrown out. Daily Herald. Retrieved from http://www.dailyherald.com/article/20150817/sports/150819163/

Valley, M. (2016, January 19). Black Lives Matter founders discuss the motives behind movement 'All black lives matter.' University Wire. Retrieved from http://ndsmcobserver.com/2016/01/the-hashtag-behind-the-new-civil-rights-movement/

Wiggins, D. K. (1993). Critical events affecting racism in athletics. In D. Brooks and R. Althouse (Eds.), Racism in college athletics: The African-American athlete's experience (pp. 23-49). Morgantown, WV: Fitness Informational Technology, Inc.

Wiggins, D. K. (1997). Glory bound: Black athletes in a White America. Syracuse, New York, NY: Syracuse University Press.

Woodson, C. G. (1933). The Mis-Education of the Negro. Washington, D.C.: Associated Publishers of America. 